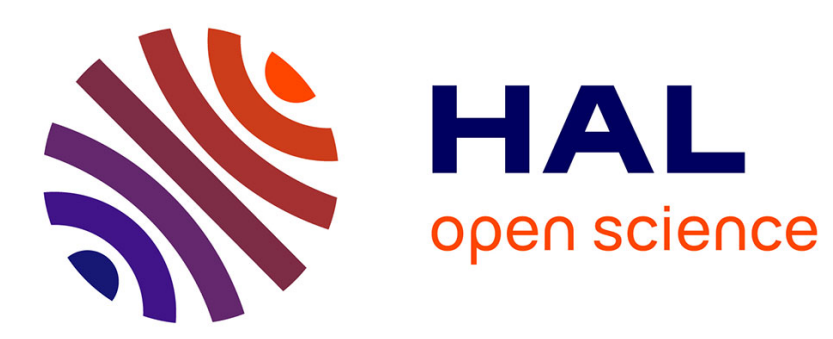

\title{
A light link coupled current monitor
}

\author{
L. Rohrer, H. Schnitter
}

\section{To cite this version:}

L. Rohrer, H. Schnitter. A light link coupled current monitor. Revue de Physique Appliquée, 1977, 12 (10), pp.1415-1416. 10.1051/rphysap:0197700120100141500 . jpa-00244336

\section{HAL Id: jpa-00244336 https://hal.science/jpa-00244336}

Submitted on 1 Jan 1977

HAL is a multi-disciplinary open access archive for the deposit and dissemination of scientific research documents, whether they are published or not. The documents may come from teaching and research institutions in France or abroad, or from public or private research centers.
L'archive ouverte pluridisciplinaire HAL, est destinée au dépôt et à la diffusion de documents scientifiques de niveau recherche, publiés ou non, émanant des établissements d'enseignement et de recherche français ou étrangers, des laboratoires publics ou privés. 


\title{
A LIGHT LINK COUPLED CURRENT MONITOR
}

\section{ROHRER and H. SCHNITTER}

Beschleunigerlaboratorium der Universität

und Technischen Universität München, 8046 Garching, Hochschulgelände, R.F.A.

\begin{abstract}
Résumé. - Nous avons développé une unité de monitorage des faibles courants dans les sections neutres et dans le terminal du Tandem MP de Munich. Ce système consiste en un convertisseur courant fréquence et une diode émettrice de lumière, alimentés par piles. Les impulsions de lumière émise sont transmises par un guide de lumière et converties dans le récepteur en un signal adapté pour la lecture. La gamme de fonctionnement va de $100 \mathrm{pA}$ à $70 \mu \mathrm{A}(1 \mathrm{nA}$ à $700 \mu \mathrm{A}$ par option) correspondant à une fréquence d'impulsion comprise entre $0,1 \mathrm{~Hz}$ et $70 \mathrm{kHz}$.
\end{abstract}

Abstract. - For small current monitoring in the dead sections and in the terminal of the Munich MP-Tandem a unit has been developed consisting of a battery operated current to frequency converter and a light emitting diode. The emitted light pulses are transmitted by a light pipe and converted to a signal suited for the display in the receiver. The operating range is from $100 \mathrm{pA}$ to $70 \mu \mathrm{A}$ ( $1 \mathrm{nA}$ to $700 \mu \mathrm{A}$ optional) corresponding to a pulse frequency between $0.1 \mathrm{~Hz}$ and $70 \mathrm{kHz}$.

1. Introduction. - To operate a modern tandem accelerator with lenses and steering elements in the accelerating section, beam current monitoring in the terminal and in the dead sections is necessary. Also for diagnostic purposes monitors for beam currents, for charging currents and column currents in the terminal, and for ionization currents near the terminal are helpful.

Therefore a system for small current measurement and data transmission has been developed. It consists of a battery operated current to frequency converter which feeds a light emitting diode, an acrylic light guide [1] connecting the emitter diode to a photodiode on ground potential, a pulse amplifier, and a frequency to voltage converter.

2. The sender. - The sender has been designed with regard to high reliability, also under surge conditions, and to low current consumption from the battery. Its circuit diagram is shown in figure 1 . The resistors $R_{1}$ and $R_{2}$ in connection with a spark gap at

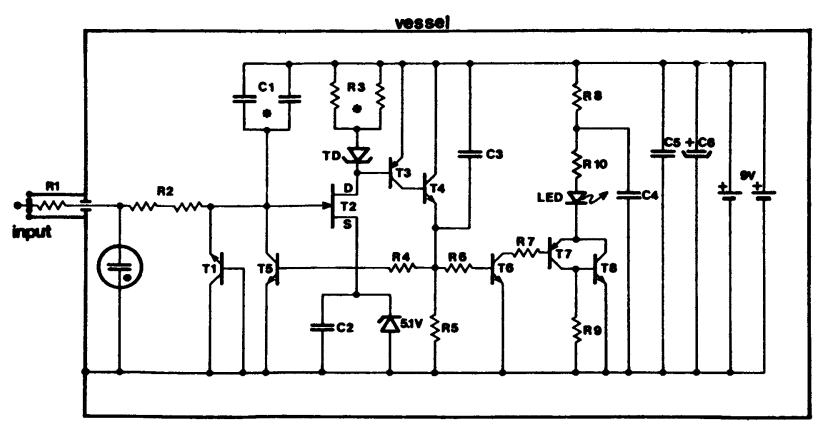

Fig. 1 the input, the surge arrestor and the transistor $T_{1}$ prevent the unit from being destroyed by sparks. The input current charges the capacitor $C_{1}$, and so a voltage ramp is generated which is applied to the FET $T_{2}$. At a certain height of the ramp (its value depends on the FET and the Z-diode), drain current begins to flow which flows also in the tunneldiode TD. When the current exceeds its peak current the tunnel-diode goes into its high state, and the transistors $T_{3}$ and $T_{4}$ are switched on. The capacitor $C_{1}$ is then discharged to ground potential by the transistor $T_{5}$, and after a short delay time, caused by the capacitor $C_{3}$, a new cycle begins. As the slope of the ramp is proportional to the input current the pulse frequency is also proportional to the input current. At each cycle the transistors $T_{6}, T_{7}$, and $T_{8}$ are switched on and supply a current pulse to the LED.

\section{TABLE I}

Parts list

$R 11.2 \mathrm{M} \Omega ; R 22 \times 47 \mathrm{k} \Omega ; R 3\left(^{*}\right)$ approx. $330 \Omega$; $R 4, R 5, R 61 \mathrm{k} \Omega ; R 7270 \Omega ; R 8220 \Omega ; R 9470 \Omega$; $R \quad 100 \ldots 10 \Omega$.

$C 1$ approx. $240 \mathrm{pF}$; $C 2100 \mathrm{nF}$; $C 310 \mathrm{pF}$; $C 4$ $100 \mathrm{nF}$; C $5220 \mathrm{nF}$; C $610 \mu \mathrm{F}$.

$T 1$ BC 183; $T 2$ BF 245; $T 3$ 2N3012; $T 4$ 2N2218; $T 5$ 2N3011; $T 6$ 2N3011; $T 7$ 2N3012; $T 82$ N5262.

TD 1N3713; LED HP 5082 - 4656.

Surge arrester type Siemens B 1 - C 90.

Batteries $2 \times 9$ V IEC 6 F 100 .

$\left({ }^{*}\right)$ Adjusted at test. 
The sender is installed in a leak and pressure tight vessel because its components, particularly the battery, would not resist to evacuating and pressurizing the accelerator tank. The vessel is also a good shield for electromagnetic fields.

The connection to the point of measurement is done by a normal unshielded wire. The dielectric material of a shielded cable would be punched through by surges, and a short circuit would be caused by the track.

3. The receiver. - The light pulses, transmitted by a light pipe, are detected by a photodiode. A preamplifier, located near the diode is used to get pulses with a logic level. From these pulses an analog signal is derived, and its value is indicated in the control room.

4. Operation. - The system is suited for input currents between $100 \mathrm{pA}$ and $70 \mathrm{nA}(1 \mathrm{nA}$ to $700 \mu \mathrm{A}$, if $C_{1}$ is modified) corresponding to a transmission frequency from $0.1 \mathrm{~Hz}$ to $70 \mathrm{kHz}$. The supply current for the sender unit is not more than a few $\mu \mathrm{A}$ at zero input, and about $1 \mathrm{~mA}$ at $1 \mu \mathrm{A}$ input current. Hence, the battery life time is more than one year.

After a prototype had been successfully tested in the accelerator, seventeen units have been installed in the Munich MP-Tandem. They have been in continous operation for about 8000 hours under normal tandem conditions, including many sparks at terminal voltages up to $12 \mathrm{MV}$.

There was no failure up to now, even the batteries had not to be exchanged. Only the PVC mounting hardware of the prototype sender has been damaged by sparks, although the unit was grounded by a wire. One can conclude from the spark distance that the surges were in the order of several hundred $\mathrm{kV}$. Therefore extremely good shielding of the electronic components is required, but it has been demonstrated that a closed steel box is a sufficient screening if an efficient surge filter is provided at the current feed through.

Acknowledgment. - The authors wish to thank S.J. Skorka who suggested this work, for many helpful discussions.

\section{References}

[1] JaKob H., Rohrer L., Schnitter H., Revue Phys. Appl. 12 (1977). 